\title{
Come sail away
}

\author{
I'm sailing away, set an open course for the virgin sea \\ 'Cause I've got to be free, free to face the life that's ahead of me \\ On board I'm the captain, so climb aboard \\ We'll search for tomorrow on every shore \\ And I'll try, oh Lord, I'll try to carry on
}

"Come Sail Away," a song by Dennis De Young of the rock group Styx, uses sailing as a metaphor for achieving one's dreams by embarking on a journey into the unknown. The first verse, quoted above (video at https://youtu.be/e5MAg_yWsq8), aptly captures the emotional excitement as well as the trepidation that I felt when in January 2016 we launched JCI Insight into uncharted waters.

I, along with a small group of ASCI staff, conceived the idea of starting a new ASCI journal in 2014, two years into my tenure as JCI Editor. While the concept of a "daughter" journal was not new in scientific publishing, it was a radical idea for the ASCI, whose membership comprises individuals spanning a wide spectrum of academic life - from young, newly elected members on a steep trajectory of scientific achievement to Senior and Emeritus members, many of whom have been elected to the National Academies of Medicine and Sciences and some of whom are Nobel laureates. As one might imagine with such a diverse range of constituencies, we received many comments, and not all of them were enthusiastic about us disrupting a more than 90-year legacy that could potentially dull the shine of the JCI brand.

However, it became clear to me after two years at the helm as Editor in Chief of the JCI that another ASCI journal was exactly what the Society needed. Armed with considerable data from our in-house IT team, I knew we could capture terrific papers that, for a variety of sound editorial reasons, were not being published in the JCI. I recognized that many of these papers were meritorious, methodologically rigorous, and, judging by their citation rate when published in other journals, important to the scientific community. And so, following a dream of mine to provide a new forum for publication of rigorous scientific biomedical investigation within the ASCI family, we set sail and created JCI Insight.

Come sail away with me

Come sail away, come sail away

In leadership circles of successful companies and organizations, one often hears stories about getting your team on the same bus and navigating your team to your destination. Bumpy roads are always in your future, but having the best team ensures your journey will end up in the right place. I could not be prouder of the entire ASCI team of dedicated staff, who together spent countless hours developing the conceptual framework and infrastructure, and attending to the numerous details that needed to be addressed in order to create and launch a new scientific journal. I knew I could rely on John Hawley, Executive Director, to provide sound reason and a calming influence; Managing Director Karen Guth for her terrific business acumen; Shawn Pyle, Associate Director, Technology, who led the team that created the Web-based platform for Insight, which went live without a hitch; Associate Director Maya Hoptman, who facilitated in-house publishing with the team in Ann Arbor, which expertly handles the production of so many papers; and, of course, the entire team for just being willing to put up with me on a daily basis!

My vision for the Journal was to provide Society members, and the scientific community at large, a nimble mechanism to publish their research findings. My criteria of what would constitute a JCI Insight paper were relatively straightforward: it needed to be rigorous and meritorious research that delved into the biology and/or treatment of human disease. On the editorial side I wanted peer review to be rapid but thoughtful. We asked reviewers to identify concerns that when addressed by the authors would make the paper better, not to give us a list of reasons to reject it.

Now, about $3 \frac{1}{2}$ years from our launch, JCI Insight has brought a new dimension to the ASCI with

Copyright: (c) 2019, American Society for Clinical Investigation.

Reference information: JCl Insight. 2019;4(15):e131371. https://doi. org/10.1172/jci.insight.131371. an additional forum for our members and other investigators to publish their work. Additionally, as outlined in our original mission statement for the Journal, it has also placed the Society on a more stable financial path. We have published more than 1500 papers with investigations into mechanisms of disease from a wide variety of medical disciplines. Published research studies range from important 
observations using human tissue, detailed mechanistic studies in experimental model systems, and early-phase human clinical trials, an area of growth of which I am particularly proud. With our peer review decision time of about 22 days, it seems we have made a wonderful start. My small team of Editors has taken an active role in adjudicating manuscripts so as to limit excessive experimentation. The Editorial Board of Yiping Yang, Rodger Liddle, Vann Bennett, Jillian Hurst, Sarah Jackson, and Corinne Williams has been amazing. I am constantly in awe of their depth of knowledge and scientific method, and I am so proud of their professionalism, integrity, and scientific rigor. I am truly indebted to their level of commitment to the editorial process.

We climbed aboard their starship, we headed for the skies

Singing, come sail away, come sail away

Well, it's time for me and the Duke-based editors to hand over the mainsheet to a new Editor and Board. I'm delighted that Kathleen Collins and her University of Michigan-based team will be leading the Journal into its next phase. As the last verse of "Come Sail Away" portrays, the captain and crew depart their earthbound sailing ship for a starship, where one can reach for the skies and embark on many new opportunities. JCI Insight is on solid footing, and I feel confident that Dr. Collins and her Board will indeed bring the Journal to new heights while also remaining true to the mission we laid out at the onset of this Journey.

Au revoir,

Howard A. Rockman, MD

Editor in Chief, JCI Insight 